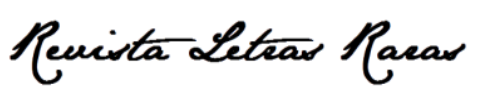

ISSN: 2317-2347 - v. 9, n. 4 (2020)

Todo o conteúdo da RLR está licenciado sob Creative Commons Atribuição 4.0 Internacional

\title{
Das moças de cachos de risos
}

\section{Damaris de Oliveira Santos*}

Doutoranda em Ciências Sociais pela Universidade Federal Rural do Rio de Janeiro - UFRRJ, possui mestrado em Ciências Sociais (2018) pela mesma universidade. Graduada em Ciências Sociais pela Universidade Federal Rural do Rio de Janeiro-UFRRJ (2015). Mobilidade acadêmica no Instituto Superior de Ciências Políticas e Sociais da Universidade de Lisboa $\left(1^{\circ}\right.$ Semestre de 2015).

iD https://orcid.org/0000-0003-1263-6594

\section{Juliana Borges de Souza*}

Doutoranda em Ciências Sociais pelo Programa de Pós-Graduação em Ciências Sociais da Universidade Federal Rural do Rio de Janeiro (PPGCS-UFRRJ). Mestra em Ciências Sociais pelo PPGCS - UFRRJ (2018), foi bolsista anos de 2016 - 2018 pela CAPES. No mestrado participou das linhas de pesquisa sobre dinâmicas sociais, práticas culturais, representações e subjetividade. Graduada em Hotelaria da Universidade Federal Rural do Rio de Janeiro (2015). Participou da pesquisa "Adoção e seus múltiplos sentidos", com bolsa de iniciação científica nos anos de 2012-2014, pela Faperj.

iD https://orcid.org/0000-0002-8960-2328

Recebido: 26 mai. 2020. Aprovado: 23 nov. 2020.

\section{Como citar este texto:}

SANTOS, Damaris de Oliveira; DE SOUZA, Juliana Borges; DE SOUSA, Juliana Marques. Das moças de cachos de risos. Revista Letras Raras, Campina Grande, v. 9, n. 4, p. 368-371, dez. 2020.

Moças de cachos de risos

Que desdizem o que diz a ciência onisciente

Que de tão mouca ficou incoerente

E de tão besta em sempre ter o que dizer, perdeu-se em seu defender

Sempre achando que sabe tudo resolver!

*

$\triangle$ damaris_osantos@hotmail.com

**

juliana_borges_souza@hotmail 


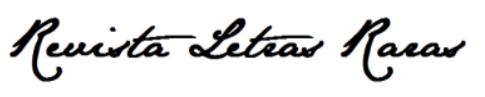

ISSN: 2317-2347 - v. 9, n. 4 (2020)

Todo o conteúdo da RLR está licenciado sob Creative Commons Atribuição 4.0 Internacional

Lenga

Leiga

Lenga

Saber o que fazer é também saber ouvir

Por que não?

Não venha intervir antes de ouvir

Conversa de só falar, nada de conversa tem.

Aborrece

Emburrece

Ensurdece

Ei, meninas de cachos de risos

DIGAM SEM MEDO DE DIZER

Se a ciência for besta e apartada do povo, não pode permanecer

A ciência se é uma coisa, é um espelho olhando para tu, bicho humano

E para o poema mais poeticamente científico ficar, coloquemos nesses versos um: portanto.

Para fim dar a problemática

Apelamos! Nos tragam "solucionáticas" como as de Dadá Maravilha

Tudo bem se a academia não aceitar

Ciência é o humano espalhado: imperfeito e sempre aberto a melhorar.

Nem rimos, nem choramos

Estamos alertas

Nas janelas agora abertas para de corpos fechados ficar

Não somos a ciência do desencanto.

Ei, mulheres com cachos e risos

O falso Messias é a bobice

Quem dera só isso fosse... 
Apenas uma tolice

Sempre foi a tortura, a perseguição, a desrazão

O corte violador da vida

Eram os Messias famintos de morte.

Eles gritam que se morrer, está morrido!

Matemos somente a enunciação da morte

Tratemos de exigir, em absoluto, a vida.

Precisamos voltar à normalidade?

Precisamos de outra normalidade.

Escolhamos ficar ao lado das moças de cachos de risos

Fazedoras de uma ciência que escuta

Estão ouvindo?

Elas são elas, pronome pessoal de tratamento feminino

Céticas demais para não ter fé

E correm com a fé, se andar não for suficiente.

Era página nove, ali, no capítulo dois

Perto do lugar de desistência de toda leitura

Era João Cabral de Melo Neto

Defendamos a vida armados de palavras.

Arranhadas

Mal apresentadas

Esperando para serem gritadas

Encarnadas que são, não as apresse

Toda palavra vira gente.

Ei, menina dos cachos de risos 
Todo o conteúdo da RLR está licenciado sob Creative Commons Atribuição 4.0 Internacional

A simplicidade é saber ouvir

Nem sempre é preciso dizer

A tua ciência também precisa saber o não dizer.

Ei, menina sem cachos de risos e de todos os amigos

$A$ vida é o desmedido

É a ciência que de atrevida virou poesia,

A poesia que de invasiva ficou científica

É a língua portuguesa da gente gritada em forma de palavra sentida. 